\title{
4 The demographic potential of Polish voivodeships and Ukrainian oblasts
}

\author{
Nataliia Chugaievska, Oleksii Kelebaj and \\ Tomasz Tokarski
}

\subsection{Introduction}

The aim of this chapter is to characterize the absolute and relative demographic potential of Polish and Ukrainian regions. In Poland, there are voivodeships (województwo), and in Ukraine oblasts (область). These analyses concern 2004-2017 (or 2004-2016) depending on the availability of statistics from the Central Statistical Data Bank (hereinafter BDL GUS, https://bdl.stat.gov.pl/https://bdl.stat.gov.pl/) and the Ukrainian Statistical Office (Державна Служба Статистики України) (hereinafter ДССУ, http:// www.ukrstat.gov.ua/http://www.ukrstat.gov.ua/).

This chapter analyzes the demographic potential of the population, population density and the division of the population into urban and rural areas. It also takes into consideration the spatial diversity and dynamics of both the population numbers and the urbanization rate.

\subsection{Administrative divisions of Poland and Ukraine}

Since January 1, 1999, Poland has been divided into 16 voivodeships. For analytical purposes, these voivodeships are divided into four groups:

- Mazowieckie,

- five voivodeship in eastern Poland (Lubelskie, Podkarpackie, Podlaskie, Świętokrzyskie and Warmińsko-Mazurskie),

- five in central Poland (Kujawsko-Pomorskie, Łódź, Małopolskie, Pomorskie and Śląskie),

- five western Polish voivodeships (Dolnośląskie, Lubuskie, Opolskie, Wielkopolskie, and Zachodniopomorskie (Map 4.1).

The Mazowieckie Voivodeship was treated as a separate entity, as it is atypical as a voivodeship. This is because it contains the capital of Poland-Warsaw and the very economically vigorous city of Płock (mainly due to the largest Polish oil company "Orlen" being based there) and the fairly weak, economically, agricultural environs surrounding Warsaw, Płock and Radom. 


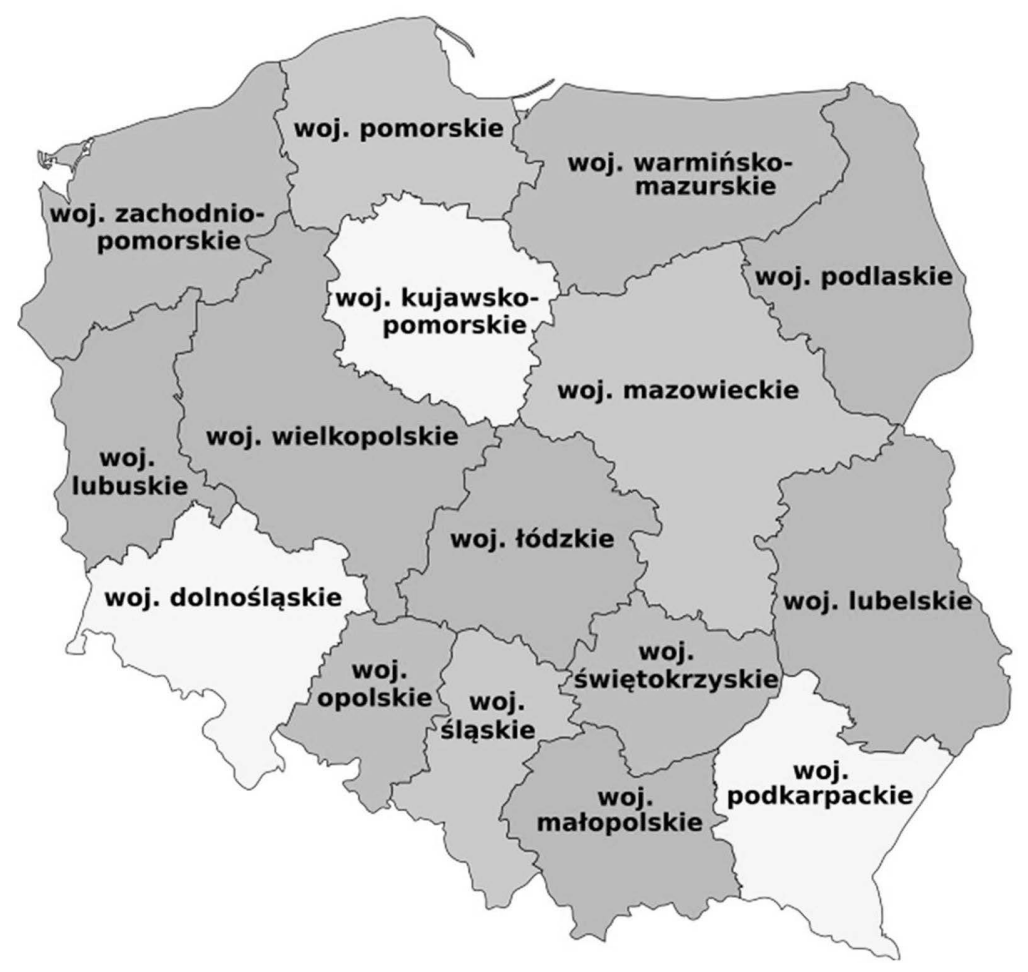

Map 4.1 Administrative division of Poland.

Source: https://pl.wikipedia.org/wiki/Podzial_administracyjny_Polska.

Eastern Poland includes areas belonging to the poorest in the European Union, which therefore benefit from the special funds provided by the European Union.

The remaining voivodeships were divided into two parallel groups consisting of the voivodeships of central and western Poland. Through the voivodeships of central Poland run the main north-south transportation routes (railway and road) connecting the Tri-city region (Tri-city - Gdańsk, Gdynia and Sopot) with Bydgoszcz, Toruń, Łódź, the Górny Śląsk-Zagłębie agglomeration and Kraków. On the other hand, the areas of the current voivodeships of western Poland were before World War I in the German partition, and in the interwar period (except for the voivodeship of Wielkopolskie) belonged to Germany (for more information on the specifics of these Polish voivodeships see: Filipowicz, Tokarski 2015, Filipowicz 2017, 2019 or Szczepaniak, Tokarski 2018).

Ukraine is divided into 24 oblasti, the Autonomous Republic of Crimea (Автономна Республіка Крим, ARC) with its capital city of Simferopol and two cities with a specific status (міста зі спеціальним статусом): Kyiv and 


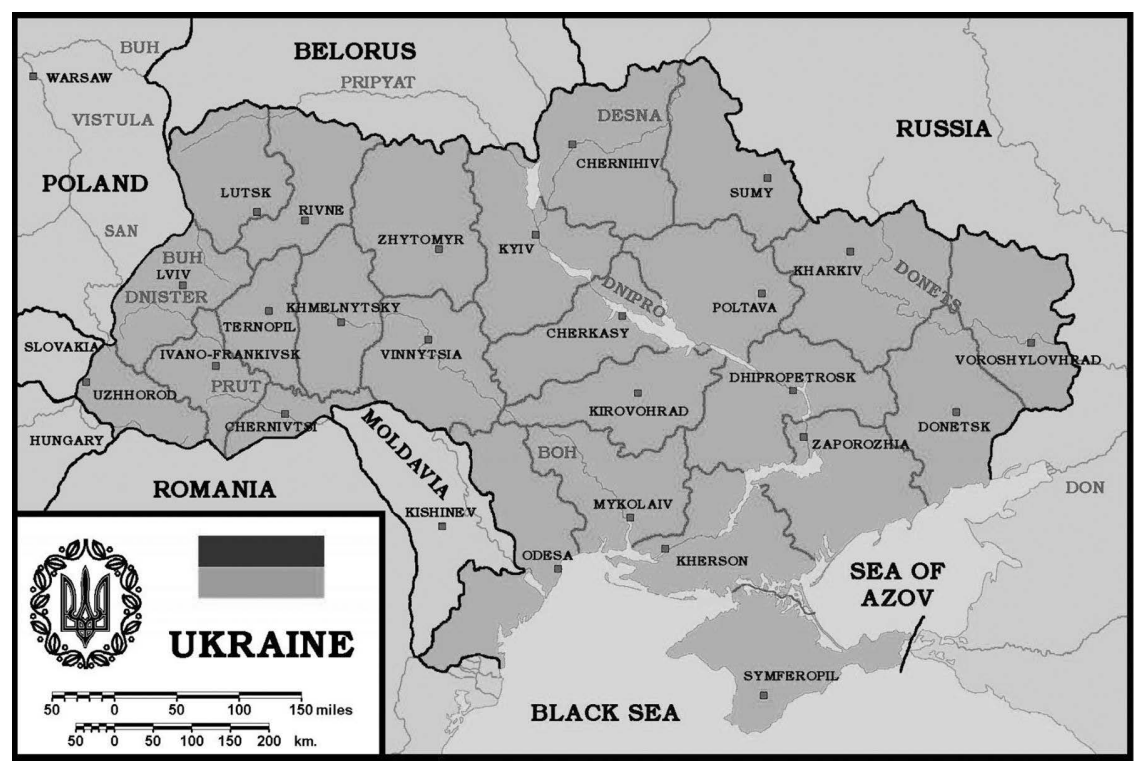

Map 4.2 Administrative division of Ukraine.

Source: http://www.ukrexport.gov.ua/eng/about_ukraine/admin/?country=ukr.

Sevastopol. Since 2014, the Autonomous Republic of Crimea and Sevastopol have been occupied by Russia (Map 4.2).

The names of most Ukrainian regions are adjectives derived from the names of their capitals, except the regions of Dnipropetrovsk Oblast, Kirovohrad Oblast, Volyn Oblast and the Zakarpattia Oblast. The capital city of the Dnipropetrovsk Oblast region is the city of Dnipro (which until 2016 was called Dnipropetrovsk) and the Kirovohrad Oblast Kropyvnytskyi (until 2016 called Kirovohrad). The capital city of the Volyn Oblast is Lutsk, while the Zakarpattia Oblast's capital is Uzhhorod. In these cases, the names of oblasts are historically contingent. The boundaries of the Volyn Oblast largely coincide with the Volyn Oblast's border of the interwar period, ${ }^{1}$ whose capital city at the time was Lutsk. The Zakarpattia Oblast belonged to the Kingdom of Hungary (a part of the Austro-Hungarian Empire) before World War I, and in the interwar period, it was in Czechoslovakia. The historic capital of the Zakarpattia region is Uzhhorod, which is currently the capital city of the Zakarpattia Oblast.

The oblasts of Ukraine are divided into five groups: ${ }^{2}$

- There are eight oblasts in western Ukraine (Khmelnytskiy, Chernivtsi, Ivano-Frankivsk, Lviv, Rivne, Ternopil, Volyn and Zakarpattia),

- The north Ukrainian oblasts (Kyiv with the regions of Chernihiv, Kyiv, Sumy and Zhytomyr), 
- There are four oblasts in eastern Ukraine (Kharkiv, Donetsk, Luhansk and Zaporizhzhya),

- The south of Ukraine has the following regions: the Autonomous Republic of Crimea, Kherson Oblast, Mykolayiv Oblast, Odesa Oblast and Sevastopol,

- Finally, there are five oblasts in central Ukraine (Cherkasy, Dnipropetrovsk, Kirovohrad, Poltava and Vinnytsya).

Located in Volyn (Волинь), the Volyn Oblast (Волинська область) and Rivne Oblast (Рівненська область) before World War I were located in the Russian Empire, near the border, while in the interwar period, they were in Poland along its eastern border. The Ivano-Frankivsk Oblast, Lviv Oblast and Ternopil Oblast until 1918 were the easternmost part of the Kingdom of Galicia and Lodomeria belonging to the Austro-Hungarian Empire (Habsburg Monarchy), while in the interwar period, this region was in Poland. Located in Bukovina (Буковина), the Chernivtsi Oblast in the years 1849-1918 was part of the Austrian Empire's Duchy of Bukovina, while between World Wars I and II, this district belonged to Romania. The Zakarpattia Oblast, until 1918, was part of the Kingdom of Hungary, while in the interwar period, Czechoslovakia. The Khmelnytskiy Oblast, located in Podilla, was in the Romanov Empire before World War I, and was part of the Soviet Union in the interwar period. After World War II (until Ukraine regained its independence in 1991), all the oblasts of western Ukraine were part of the Ukrainian Soviet Socialist Republic, which in turn was part of the Soviet Union.

It can be concluded that the oblasts of western Ukraine over the past 200 years have been the outermost areas of the countries to which they belonged. This was not an aid in fostering neither their social or political stability nor their economic development (see: for example, Hrycak 2000; Serczyk 2001 or Hud 2018).

The districts belonging to the remaining provinces (in particular those areas located in Ukraine, on the right (west) bank of the Dnieper River ${ }^{3}$ and the coastal oblasts, i.e., of the Odesa Oblast, Mykolayiv Oblast and Kherson Oblast) in the19th and 20th centuries were much more (than the oblasts of western Ukraine) politically and economically integrated first with tsarist Russia, and subsequently with the USSR. Therefore, their history, social, political and economic relations differed significantly from what was taking place in western Ukraine (see Hrycak 2000; Serczyk 2001; Wyszczelski 2015 or Hud 2018).

\subsection{The demographic potential of the Polish voivodeships}

Statistical data describing the voivodeships and the above-mentioned groups of voivodeships relate to the area and population at the beginning and end of the time period considered in this chapter. 
From statistical data, it can be concluded that:

- the largest voivodeships in terms of area are the Mazowieckie (11.4\% of Poland), Wielkopolskie $(9.5 \%)$ and Lubelskie $(8.0 \%)$. The smallest voivodeships include the Śląskie (3.9\%), Świętokrzyskie (3.7\%) and Opolskie (3.0\%);

- The voivodeships of eastern Poland occupy $31.7 \%$ of the country's area, while those of western Poland $30.7 \%$ and central Poland 26.2\%;

- On average, in the years 2004-2017 the largest population was recorded in the Mazowieckie Voivodeship (13.7\% of the Polish population), followed by the Śląskie $(12.1 \%)$ and Wielkopolskie $(9.0 \%)$ voivodeships. The lowest number of inhabitants was found in the following voivodeships: the Podlaskie (3.1\%), Opolskie (2.7\%) and Lubuskie (2.6\%) (Map 4.3);

- At the time, $38.7 \%$ of Poland's population lived in central Poland, the provinces of western Poland had 26.3\%, while eastern Poland had only $21.3 \%$ of the country's overall population.

- Between 2004 and 2017, the population in 10 of the 16 voivodeships increased, while in the others, it decreased. The largest relative increases were recorded in the following voivodeships: Pomorskie $(5.9 \%)$, Mazowieckie (4.6\%), Małopolskie (4.0\%) and Wielkopolskie $(3.7 \%)$

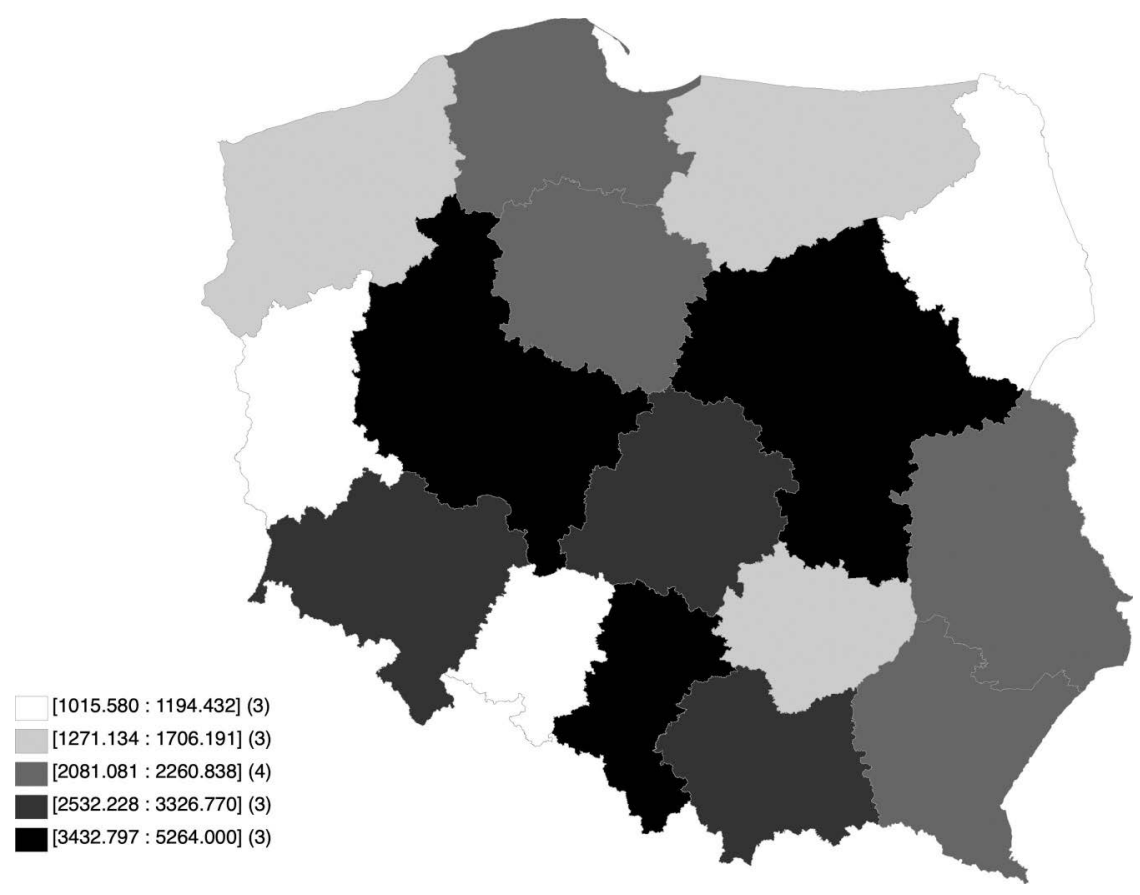

Map 4.3 Population in voivodeships, between 2004 and 2017 (1,000 people).

Source: Our own estimates based on: https://bdl.stat.gov.pl/BDL/start (access: 2019-12-30). 


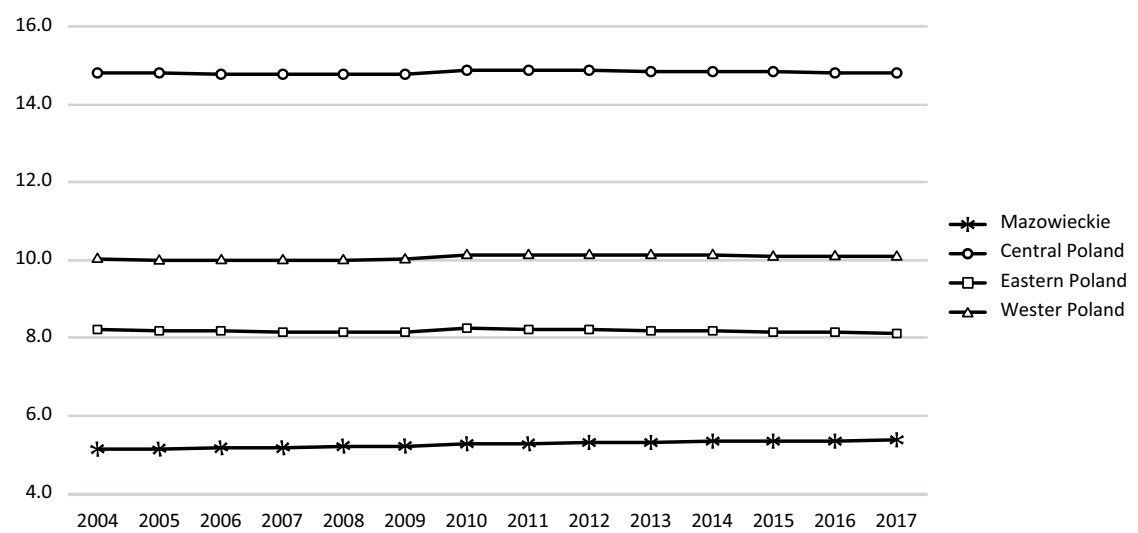

Figure 4.1 Population in groups of voivodeships, between 2004 and 2017 (million people).

Source: Our own estimates based on: https://bdl.stat.gov.pl/BDL/start (access: 2019-12-30).

The highest decreases were recorded in the Opolskie Voivodeship (a decrease of $5.8 \%$ ), followed by the Lódzkie (4.3\%), Śląskie and Świętokrzyskie (3.2\%), Lubelskie (2.7\%) and Podlaskie (1.5\%) voivodeships (Figure 4.1). Hence we may come to a more general conclusion that in the years 2004-2017, Polish population growth was mainly characterized by those voivodeships with demographically and economically strong urban centers (Warsaw, Kraków, Poznań and the Tri-City area), while a decline in population occurred in either the post-industrial voivodeships (Lódzkie and Śląskie) or the voivodeships of eastern Poland (see: Trojak, Tokarski 2013; Filipowicz, Tokarski 2015; Trojak 2015; or Szczepaniak, Tokarski 2018).

- Regarding the groups of voivodeships, in western Poland the population in the research period increased by $0.9 \%$, in central Poland by $0.1 \%$, while in the voivodeships of eastern Poland decrease by 1.0\%.

- In 2017, the Śląskie Voivodeship had the highest population density (369.8 persons $/ \mathrm{km}^{2}$,), with an average population density in Poland of 122.9 persons $/ \mathrm{km}^{2}$. The next in order were the following provinces: Małopolskie (223.1 persons $/ \mathrm{km}^{2}$ ), Mazowieckie (151.3 persons/ $\mathrm{km}^{2}$ ), Dolnośląskie (145.9 persons $/ \mathrm{km}^{2}$ ) and Łódzkie (136.1 persons/ $\mathrm{km}^{2}$ ). The lowest value of this characteristic (i.e., less than 100 people $\left./ \mathrm{km}^{2}\right)$ was recorded in the following voivodeships: Lubelskie $(84.7$ people $/ \mathrm{km}^{2}$ ), Warmińsko-Mazurskie (59.3 people $/ \mathrm{km}^{2}$ ) and Podlaskie (58.6 people $/ \mathrm{km}^{2}$ ) in eastern Poland, and the Zachodniopomorskie (74.5 people $\left./ \mathrm{km}^{2}\right)$ and Lubuskie $\left(72.6\right.$ people $\left./ \mathrm{km}^{2}\right)$ voivodeships in western Poland. 
- The average population density of central Poland was 180.8 people $/ \mathrm{km}^{2}$ and in western Poland 105.3 people $/ \mathrm{km}^{2}$, while eastern Poland had only 82.0 people $/ \mathrm{km}^{2}$.

- The areas of eastern Poland are characterized by a much lower demographic potential (measured both in population and in population density) than in other regions of Poland.

- Below are the statistical data on the population of cities that in 2004 or 2017 had more than 200,000 inhabitants.

- In 2004, there were 18 cities in Poland of over 200,000 and in 2017, only 16 cities (the population of Gliwice and Kielce dropped below 200,0004). Among these cities, both in 2004 and 2017, there was one city of over a million (Warsaw), and four with a population between 500,000 and one million people (Kraków, Łódź, Wrocław and Poznań) and 13 cities in 2004 and 11 cities in 2017 with a population between 200,000 and 500,00 people.

- In total, $21.5 \%$ of the Polish population in 2004 and $20.9 \%$ in 2017 lived in the analyzed group of cities. Those cities with a population exceeding 500,000 persons were inhabited by some $11.6 \%$ (2004) and $11.4 \%$ (2017) of the Polish population in general.

- In the Mazowieckie Voivodeship, two cities with a population of over 200,000 persons (Warsaw and Radom) had 37.3\% of the inhabitants of this voivodeship in 2004 and $36.8 \%$ in 2017. Similar indicators for the remaining groups of voivodeships were as follows: in eastern Poland three cities in 2004 (Lublin, Białystok and Kielce) and two cities in 2017 (Lublin and Białystok) constituted (respectively) $10.5 \%$ and $7.8 \%$ of the population of these voivodeships. Central Poland had ten cities in 2004 (Kraków, Łódź, Gdańsk, Bydgoszcz, Katowice, Gdynia, Częstochowa, Sosnowiec, Torun and Gliwice), and nine in 2017 (those previously listed with the exception of Gliwice), $25.8 \%$ of their respective voivodeship populations in 2004, and 23.3\% in 2017. In western Poland three cities (Wrocław, Poznań and Szczecin) had 16.2\% of their respective voivodeship populations in 2004, and $15.6 \%$ in 2017.

- In five Polish cities, the population in 2017 was higher than in 2004: Warsaw had an increase in the number of inhabitants by $4.2 \%$, Białystok $1.8 \%$, Kraków 1.3\%, Gdańsk $1.1 \%$ and Wrocław $0.4 \%$. The largest relative decreases in population were recorded in Częstochowa and Gliwice (a decrease of 9.5\%), and in Sosnowiec (10.6\%) and Lódź (10.8\%).

- It is worth noting that the decrease in the population in some of these cities (with the exception of Częstochowa, Łódź, Radom and the cities of the Górny Śląsk-Zagłębie agglomeration, i.e., Gliwice, Katowice and Sosnowiec) was compensated for by an increase in the population in the districts neighboring these cities. The total population of Warsaw with neighboring municipalities increased from 2.5 million people in 2004 to 2.9 million people in 2017 (i.e., by 8.9\%), Poznań and the Poznań 
district grew from 851.700 persons to 920.300 persons $(8.0 \%)$, the TriCity region with neighboring districts went from 1.3 million people up to 1.4 million people $(7.4 \%)$, Kraków and neighboring districts with 1.2 million people increased to 1.3 million people $(6.1 \%)$, Wrocław and its surroundings with 1.0 million people went up to 1.1 million people (5.2\%), Torun and the Torun district from 295.400 persons up to 308.200 persons (4.3\%), Białystok and the Białystok district from 431.200 persons up to 444.300 persons (3.0\%), Szczecin and neighboring district from 755.200 persons up to 767.800 persons $(1.7 \%)$ or Bydgoszcz and the Bydgoszcz district from 461.100 persons to 468.300 persons (1.6\%). The population of Kielce and the Kielce district did not change in 20042017 (it amounted to 406.900 people), while in Lublin and the Lublin district the number of inhabitants dropped from 567.300 persons to 565.600 persons $(0.3 \%)$, in Radom and the Radom district from 372.000 persons to 366.500 persons (1.5\%), in Czestochowa and the Czestochowa district from 381.900 persons to 359.600 persons (5.8\%), in Łódź with its neighboring districts from 1.1 million people down to 1.0 million people (by 6.4\%) and in the urban districts of the Górny ŚląskZagłębie agglomeration this chart dropped from 2.3 million people to two million people (by 7.1\%).

- In the Mazowieckie Voivodeship, the population of Warsaw and Radom together with their surrounding areas increased by $7.7 \%$, in the large cities of western Poland and neighboring districts this chart increased by $5.1 \%$ and in eastern Poland by $0.8 \%$, while in central Poland this chart fell by $1.0 \%$.

- The total population in the 18 large Polish cities and the neighboring districts mentioned above increased in 2004-2017 from 14.1 million people to 14.4 million people (by $2.2 \%$ ). It can be stated that some inhabitants of large Polish cities change their place of residence by moving to districts neighboring these cities.

- In 2004, 46.5\% of the population of those cities of over 200,000 lived in central Poland, 23.4\% in Mazowieckie, 19.7\% in western Poland and only $10.9 \%$ in eastern Poland. In 2017, these indicators were (respectively) 45.1\% central Poland, 25.9\% Mazowieckie Voivodeship, 20.7\% western Poland and $8.3 \%$ eastern Poland. This leads to the conclusion that the voivodeships of eastern Poland not only have a lower demographic potential but also have a much weaker potential of the population living in cities of over 200,000.

Tables 4.1 and 4.2 present statistical data on the number of people living in cities and in the countryside, both in individual voivodeships and in the previously distinguished groups of voivodeships in 2004 and 2017. Data regarding the number of inhabitants are divided into urban and rural districts. 


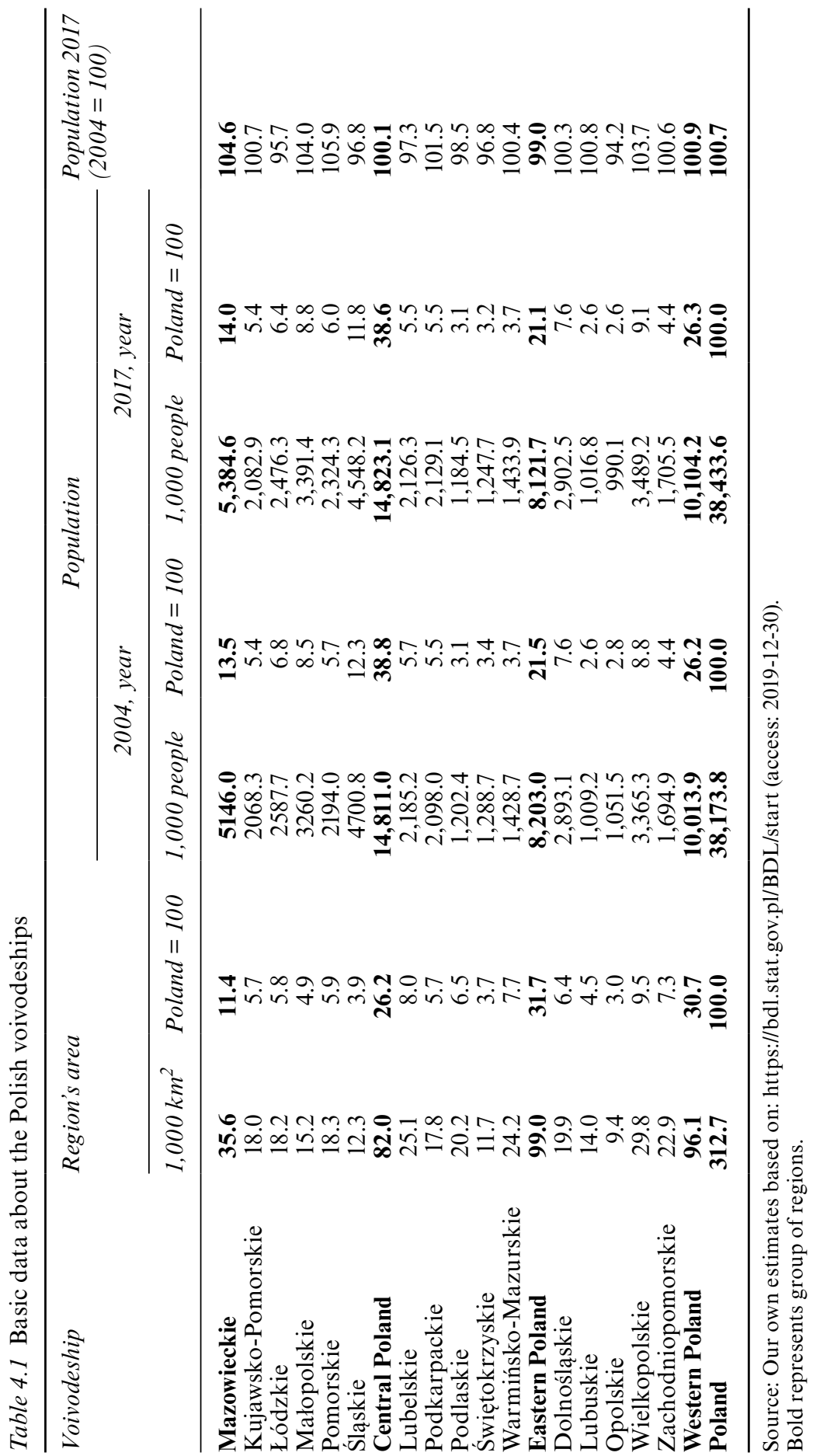


66 Nataliia Chugaievska et al.

Table 4.2 The population of Polish cities with more than 200,000 inhabitants in 2004 and 2017 (1,000 people)

\begin{tabular}{|c|c|c|c|c|}
\hline \multirow[t]{2}{*}{ City } & \multirow{2}{*}{$\begin{array}{l}\text { Voivodeship or group } \\
\text { of voivodeships }\end{array}$} & \multicolumn{2}{|c|}{ Year } & \multirow{2}{*}{$\begin{array}{l}\text { Population in } 2017 \\
(\text { year } 2004=100)\end{array}$} \\
\hline & & 2004 & 2017 & \\
\hline Warszawa & Mazowieckie & $1,692.9$ & 1764.6 & 104.2 \\
\hline Kraków & Małopolskie & 757.4 & 767.3 & 101.3 \\
\hline Łódź & Łódzkie & 774.0 & 690.4 & 89.2 \\
\hline Wrocław & Dolnoślaskie & 636.3 & 638.6 & 100.4 \\
\hline Poznań & Wielkopolskie & 570.8 & 538.6 & 94.4 \\
\hline Gdańsk & Pomorskie & 459.1 & 464.3 & 101.1 \\
\hline Szczecin & Zachodniopomorskie & 411.9 & 403.9 & 98.1 \\
\hline Bydgoszcz & Kujawsko-Pomorskie & 368.2 & 352.3 & 95.7 \\
\hline Lublin & Lubelskie & 356.0 & 339.9 & 95.5 \\
\hline Białystok & Podlaskie & 292.2 & 297.3 & 101.8 \\
\hline Katowice & Śląskie & 319.9 & 296.3 & 92.6 \\
\hline Gdynia & Pomorskie & 253.3 & 246.3 & 97.2 \\
\hline Częstochowa & Śląskie & 248.0 & 224.4 & 90.5 \\
\hline Radom & Mazowieckie & 227.6 & 214.6 & 94.3 \\
\hline Sosnowiec & Śląskie & 228.2 & 204.0 & 89.4 \\
\hline Toruń & Kujawsko-Pomorskie & 208.3 & 202.6 & 97.3 \\
\hline Kielce & Świętokrzyskie & 209.5 & 196.8 & 94.0 \\
\hline Gliwice & Śląskie & 200.4 & 181.3 & 90.5 \\
\hline Mazowieckie & & $1,920.5$ & $1,979.2$ & 103.1 \\
\hline \multirow[t]{2}{*}{ Central Poland } & & $3,816.8$ & $3,629.2^{\mathrm{a}}$ & $95.1^{\mathrm{a}}$ \\
\hline & & & $3,447.6^{\mathrm{b}}$ & $90.3^{b}$ \\
\hline \multirow[t]{2}{*}{ Eastern Poland } & & 857.6 & $833.9^{\mathrm{c}}$ & $97.2^{\mathrm{c}}$ \\
\hline & & & $637.1^{\mathrm{d}}$ & $72.3^{d}$ \\
\hline Western Poland & & $1,618.9$ & 1581.1 & 97.7 \\
\hline \multirow[t]{2}{*}{ Poland } & & $8,213.8$ & $8,023.4^{\mathrm{e}}$ & $97.7^{\mathrm{e}}$ \\
\hline & & & $7,645.3^{\mathrm{f}}$ & $93.1^{\mathrm{f}}$ \\
\hline
\end{tabular}

Source: Our own estimates based on: https://bdl.stat.gov.pl/BDL/start (access: 2019-12-30).

a With Gliwice.

b Without Gliwice.

c With Kielce.

d Without Kielce.

e With Gliwice and Kielce.

f Without Gliwice and Kielce.

From statistical data, it can be concluded that:

- Both in 2004 and 2017, the quartile group ${ }^{5}$ with the largest population living in cities included the following voivodeships: Śląskie, Mazowieckie, Dolnośląskie and Wielkopolskie. These values were at a level of 3.7 million people in 2004 and 3.5 million people in 2017 in the Śląskie Voivodeship, 3.3 million people and 3.5 million people in the Mazowieckie Voivodeship, 2.1 million people and 2.0 million people in the Dolnośląskie Voivodeship and 1.9278 million persons, and 1.9034 million persons in the Wielkopolskie Voivodeship, whereas the quartile group 
with the smallest value of the variable analyzed here was composed of two voivodeships in eastern Poland and two in western Poland. In the cities, in the Podlaskie Voivodeship, there were in $2004-710.800$ people and in 2017 - 719.200 people, in Lubuskie Voivodeship in 2004 - 648.200 people and in 2017 - 659.700 people, in Świętokrzyskie Voivodeship in 2004 - 586.700 people and in 2017 - 556.200 people, while in the Opolskie Voivodeship in 2004 - 554.000 people and in 2017 - 522.600 people.

- In five voivodeships, the number of urban residents in 2017 was higher than in 2004, while in the remaining 11 voivodeships, it was lower. The population of cities increased the fastest in the Mazowieckie (by $4.0 \%$ ), Podkarpackie (3.2\%), Lubuskie $(1.8 \%)$ and Podlaskie $(1.2 \%)$ voivodeships. However, the population of cities fell the fastest in the following voivodeships: Świętokrzyskie (by 5.2\%), Śląskie (5.6\%), Opolskie (5.7\%) and Łódź (7.3\%).

- In 2004, 41.6\% of the inhabitants of Polish cities lived in the cities of central Poland, 27.1\% in western Poland, 17.1\% in eastern Poland, and the remaining $14.2 \%$ of the urban population in the Mazowieckie Voivodeship. In 2017, these percentage rates were $40.7 \%$ in central Poland, 27.1\% in western Poland, 17.3\% in eastern Poland and 15.0\% in the Mazowieckie Voivodeship.

- In 2017, the number of urban residents in the Mazowieckie Voivodeship was $4.0 \%$ higher than in 2004 , while in other groups of voivodeships the value of this demographic variable decreased. In the voivodeships of central Poland, the value of this trait decreased in $2004-2017$ by $3.6 \%$, in western Poland by $1.7 \%$ and in eastern Poland - by $1.0 \%$.

- When analyzing the number of inhabitants of cities that are in urban districts, it turns out that in 2017 this chart fell in Poland by $1.8 \%$ compared to 2004. It should be noted, however, that declines of this magnitude were not evenly distributed geographically. In the voivodeships of western Poland the value of this variable increased by $2.6 \%$, in the Mazowieckie Voivodeship by $2.3 \%$, while in the voivodeships of eastern Poland by $1.1 \%$ and central Poland by $5.3 \%$ (mainly as a result of processes of demographic trends taking place in the post-industrial Śląskie and Łódzkie voivodeships).

- In six voivodeships (Dolnośląskie, Lubuskie, Podkarpackie, Mazowieckie, Podlaskie and Małopolskie) the number of inhabitants of urban districts increased, while in the remaining voivodeships it decreased. The largest relative increases (by more than $5 \%$ ) in the value of this variable considered here between 2004 and 2017 were recorded in the Dolnośląskie (by $12.4 \%$ ) and Lubuskie (8.2\%) voivodeships in western Poland and the Podkarpackie $(6.3 \%)$ Voivodeship in eastern Poland. The largest decreases were recorded in the Wielkopolskie Voivodeship (a 5.5\% drop) in western Poland, in the Świętokrzyskie Voivodeship $(6.0 \%)$ in eastern Poland and (as already mentioned) the post-industrial Śląskie (8.1\%) and Łódzkie (by 9.9\%) voivodeships in central Poland. 
- The population of cities in rural voivodeships between 2004 and 2017 in Poland fell by $1.2 \%$. In the Mazowieckie Voivodeship the value of this variable increased by $7.2 \%$, while in the other groups of voivodeships it decreased. In the voivodeships of western Poland, the population of cities in rural districts fell by $4.6 \%$, in eastern Poland by $0.9 \%$, while in central Poland by $0.6 \%$. In the voivodeships of central Poland, the number of people living in towns in rural districts decreased in 2004-2017 by $4.6 \%$, in western Poland by $0.9 \%$ and eastern Poland by $0.6 \%$.

- In seven voivodeships (except for the Mazowieckie Voivodeship, also in the voivodeships: Pomorskie, Wielkopolskie, Małopolskie, Podkarpackie, Podlaskie and Zachodniopomorskie), the value of the variable considered here increased, in the others it decreased. The highest relative increases were recorded in the Pomorskie (by 2.6\%) and Małopolskie $(2.3 \%)$ voivodeships in central Poland, while the largest decreases were recorded in the following voivodeships: Lódzkie (4.1\%) in central Poland, Świętokrzyskie (4.7\%) in eastern Poland and Opolskie (7.2\%) and Dolnośląskie (13.0\%) in western Poland.

- In 2017, 4.2\% more people lived in the Polish countryside than in 2004. The fastest growing population living in the countryside was in central Poland (by 7.2\%), then in Mazowieckie (5.8\%) and western Poland $(5.4 \%)$, while in rural eastern Poland the value of this variable dropped by $1.0 \%$.

- In 11 voivodeships the percentage of those living here increased, while in the remaining five voivodeships (Lubuskie, Świętokrzyskie, Lubelskie, Podlaskie and Opolskie) it decreased. The highest relative increments of this variable were recorded in the following voivodeships: Pomorskie (17.1\%), Wielkopolskie (10.3\%), Dolnośląskie (7.9\%) and KujawskoPomorskie (7.1\%). In the Lubuskie Voivodeship, the population living in the countryside dropped by $1.1 \%$, in Świętokrzyskie by $1.5 \%$, Lubelskie by $2.3 \%$, Podlaskie by $5.3 \%$ and Opolskie by $6.0 \%$.

Map 4.4 shows the geographic diversity of urbanization rates in Poland, on the average, in 2005-2017, while Figure 4.2 shows the trajectories of these rates in the groups of the voivodeships researched in the period of time analyzed here. From the map and graph mentioned here as well as statistical data on urbanization rates in these voivodeships, the results are as follows:

- The highest urbanization rates in the years 2005-2017 were recorded in central Poland (64.6\%), followed by Mazowieckie (64.4\%), and western Poland $(62.5 \%)$, while the lowest values of this feature were recorded in the agricultural voivodeships of eastern Poland (only 49.1\%, with an average percentage for Poland as a whole of $60.7 \%$ ).

- The quartile group with the highest urbanization rates included the following voivodeships: Śląskie (77.7\%), Dolnośląskie (69.9\%), Zachodniopomorskie (68.8\%) and Pomorskie (65.6\%). However, the quartile group 
[41.049: 46.447] (3) [48.963: 55.732] (3)

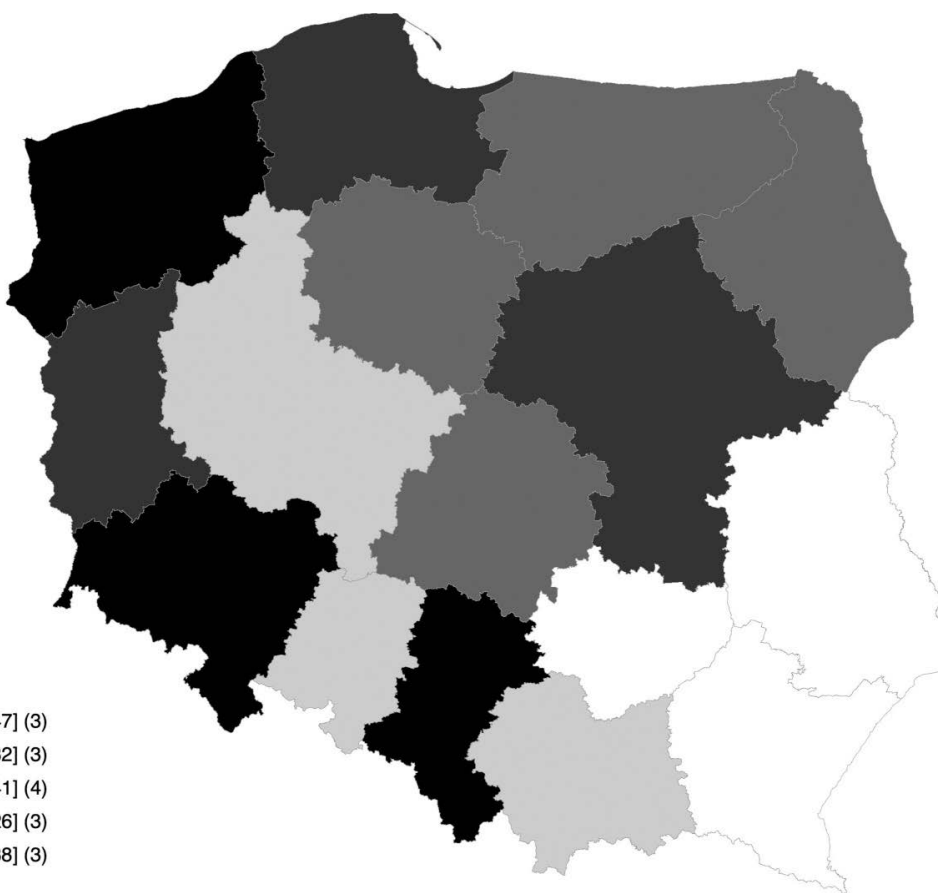

Map 4.4 Average urbanization rates in voivodeships in 2005-2017 (\%).

Source: Our own estimates based on: https://bdl.stat.gov.pl/BDL/start (access: 2019-12-30).

with the lowest value of this variable was composed of the Małopolskie Voivodeship ${ }^{6}(49.0 \%)$ in central Poland and three voivodeships in eastern Poland: the Lubelskie (46.4\%), Świętokrzyskie (45.0\%) and Podkarpackie $(41.0 \%)$.

- Urbanization rates in the agricultural voivodeships of eastern Poland were over 15 percentage points lower than in the Mazowieckie Voivodeship, whereas in the voivodeships of western Poland these rates were almost 2 percentage points lower than in the aforementioned voivodeship. Urbanization rates in the Mazowieckie Voivodeship and central Poland were similar.

- In the least urbanized voivodeships of eastern Poland, the urbanization rate increased by $0.1 \%$ point between 2005 and 2017. In other groups of voivodeships, this rate was falling. In the Mazowieckie Voivodeship, the urbanization rate dropped by $0.4 \%$ point, in western Poland by 1.5 percentage points and central Poland by 2.2 percentage points (mainly as a result of the de-urbanization of the Śląskie and Lódzkie voivodeships).

- When comparing the urbanization rates in individual voivodeships in 2017 with those recorded in 2005 , it turns out that in 3 voivodeships 


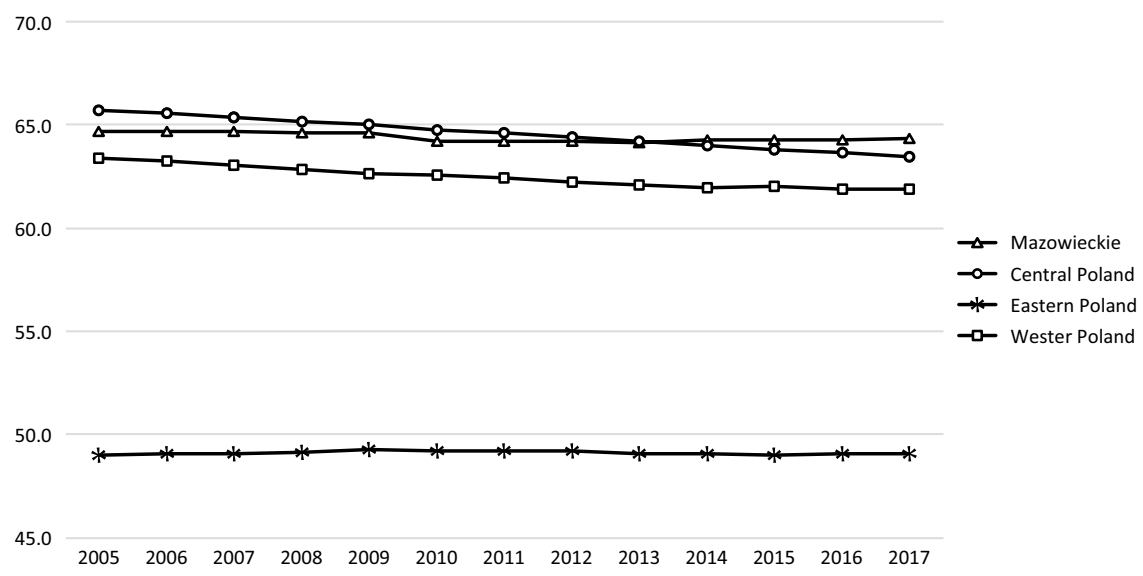

Figure 4.2 Urbanization rates in 2005-2017 (\%).

Source: Our own estimates based on: https://bdl.stat.gov.pl/BDL/start (access: 2019-12-30).

(Podlaskie, Podkarpackie and Lubuskie) these rates increased, while in the others they fell. In the Podlaskie Voivodeship, the urbanization rate increased by 1.5 percentage points, while in the Podkarpackie and Lubuskie voivodeships by 0.8 percentage point. The largest decreases in the rate considered here were recorded in the Kujawsko-Pomorskie (2.2 percentage points), Dolnośląskie (2.3 percentage points), Wielkopolskie (2.5 percentage points) and Pomorskie (3.4 percentage points) voivodeships. In Poland, the urbanization rate then fell by 1.3 percentage points.

\subsection{Demographic potential of the Ukrainian oblasts}

Tables 4.3 and 4.4 present basic statistical data describing oblasts and group of oblasts. These data relate to the area and population at the beginning and end of the time period considered in this chapter and in 2013, that is, the last year in which the Autonomous Republic of Crimea and Sevastopol were actually part of Ukraine.

From statistical data it can be concluded that:

- The largest quartile group includes the following oblasts: Odesa in southern Ukraine (5.5\% of Ukraine, $5.8 \%$ of Ukraine without the Autonomous Republic of Crimea and Sevastopol), Dnipropetrovsk Oblast $(5.3 \%, 5.5 \%)$ in central Ukraine, Chernihiv Oblast (5.3\%, 5.5\%) in northern Ukraine, Kharkiv Oblast $(5.2 \%, 5.4 \%)$ in eastern Ukraine, Zhytomyr Oblast $(4.9 \%, 5.2 \%)$ in northern Ukraine and the Poltava Oblast $(4.8 \%, 5.0 \%)$ in central Ukraine. The special status cities were the smallest in terms of area of the oblasts: Kyiv $(0.1 \%, 0.1 \%)$ in northern Ukraine 


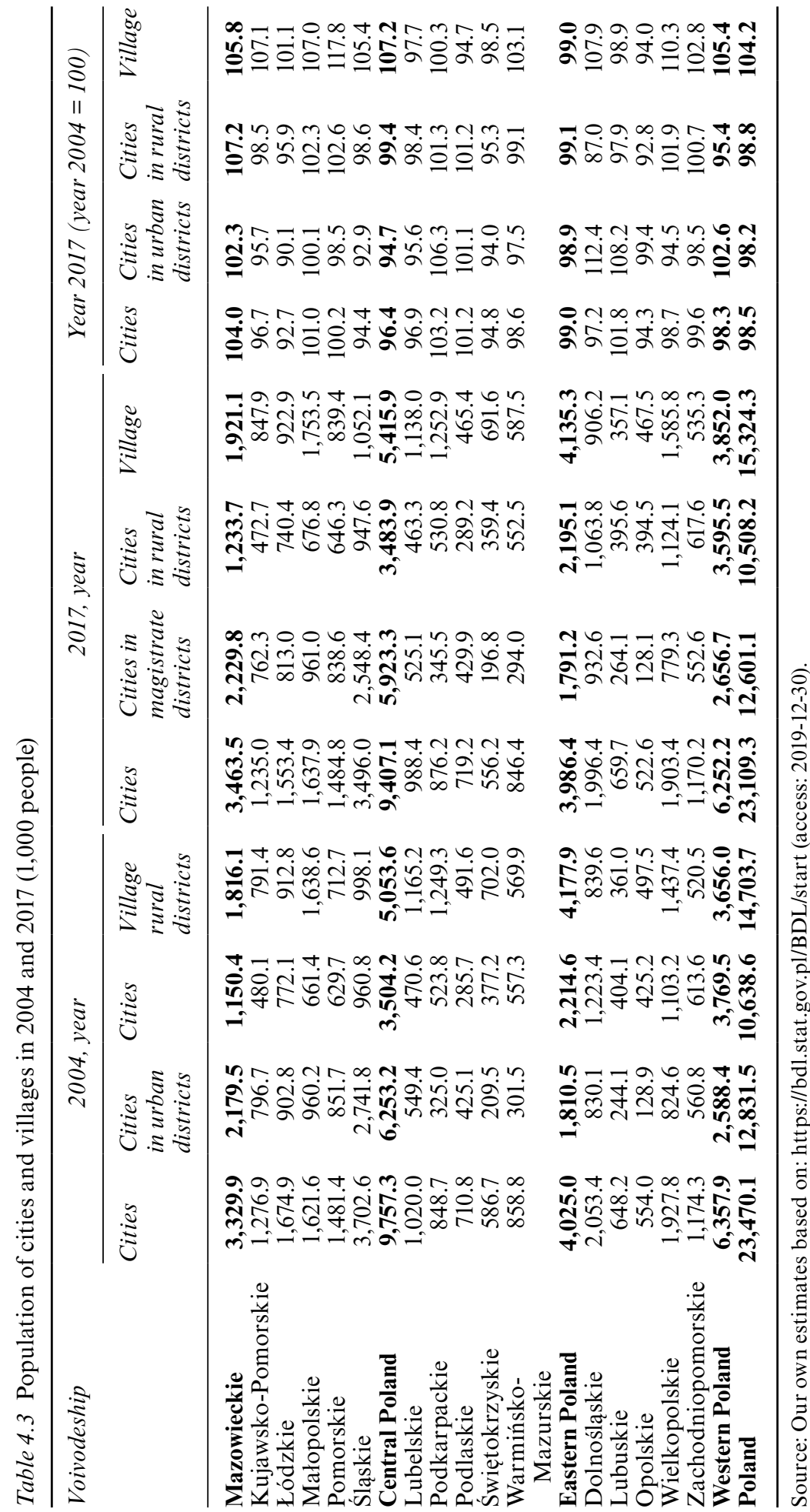




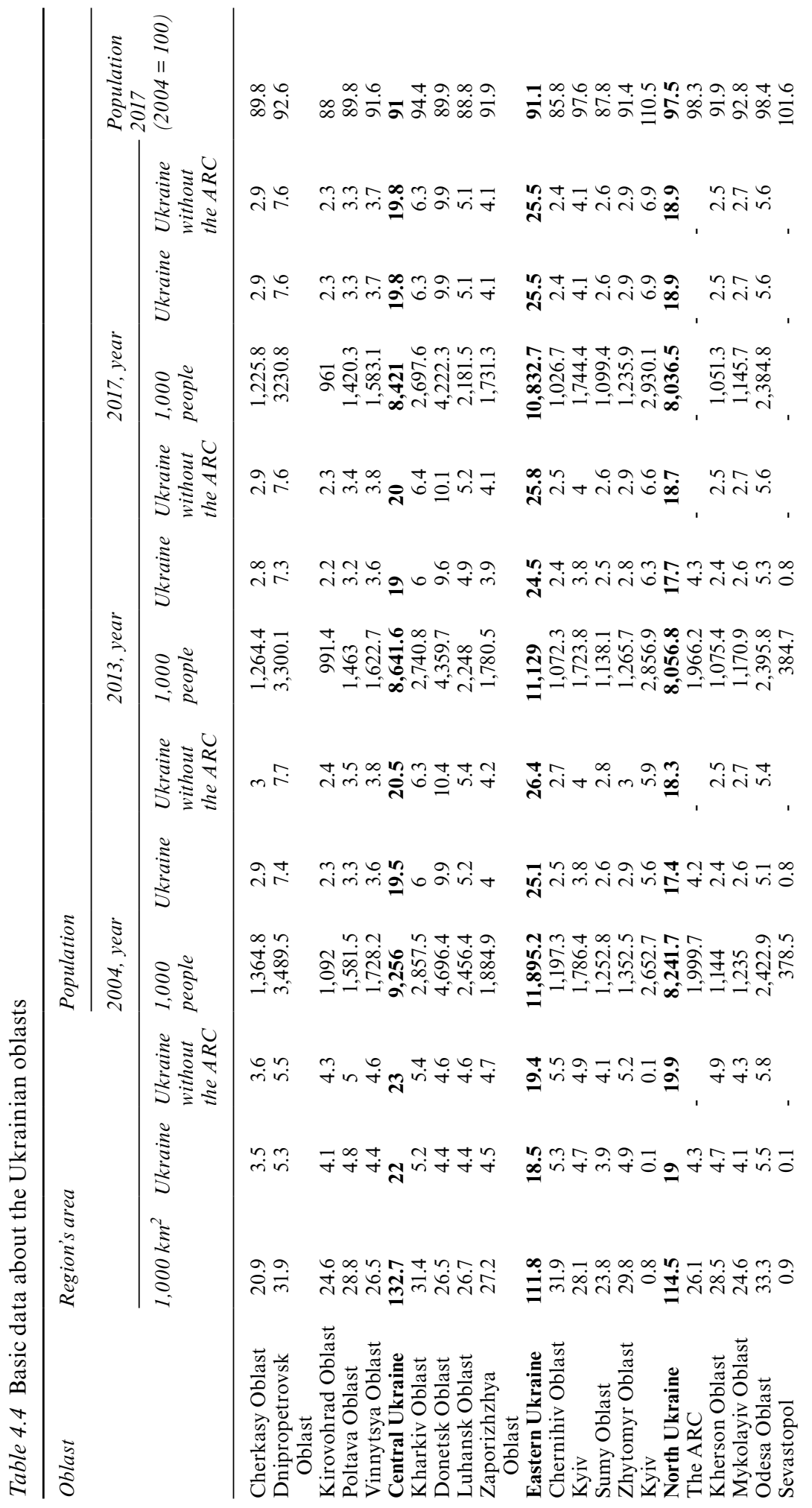




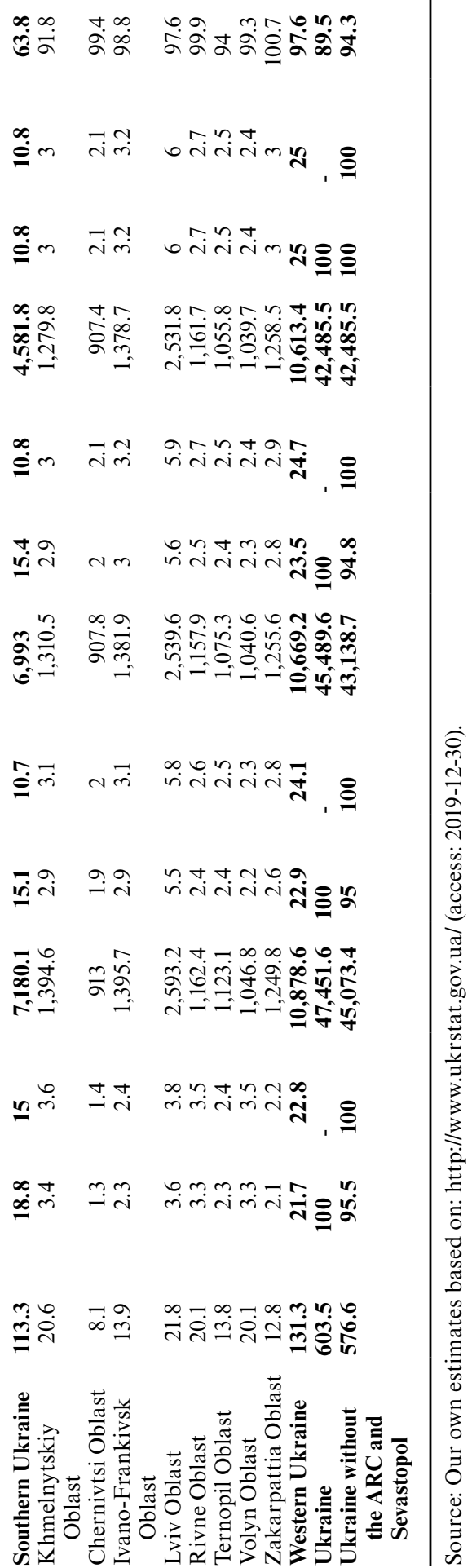


and Sevastopol $(0.1 \%)$ in southern Ukraine and the following oblasts in western Ukraine: Chernivtsi $(1.3 \%, 1.4 \%)$, Zakarpattia $(2.1 \%, 2.2 \%)$, Ternopil $(2.3 \%, 2.4 \%)$ and Ivano-Frankivsk $(2.3 \%, 2.4 \%)$.

- The largest part of Ukraine is the oblast of central Ukraine $(22.0 \%$ of Ukraine, $23.0 \%$ of the country without the Autonomous Republic of Crimea and Sevastopol). Next in terms of the value of this feature are the oblasts of western Ukraine $(21.7 \%, 22.8 \%)$, northern Ukraine $(19.0 \%, 19.9 \%)$, southern Ukraine $(18.8 \%, 15.0 \%)$ and eastern Ukraine $(18.5 \%, 14.9 \%)$.

- In 2004, the quartile group with the greatest demographic potential was composed of the Donetsk Oblast in the east of Ukraine $(9.9 \%$ of the population of the country), Dnipropetrovsk in the center (7.4\%), Kharkiv in the east $(6.0 \%)$, Kyiv in the north (5.6\%), and the Lviv Oblast in the west $(5.5 \%)$ and the Luhansk oblast in the east of Ukraine (5.2\%). Sevastopol $(0.8 \%)$ in the south of Ukraine and the following oblasts: Chernivtsi $(1.9 \%)$ and Volyn (2.2\%) in western Ukraine, and Kirovohrad (2.3\%) in central Ukraine belonged to the oblasts with the lowest population numbers at the time, Ternopil $(2.4 \%)$ in western Ukraine and Kherson $(2.4 \%)$ in southern Ukraine.

- $25.1 \%$ of the population of Ukraine lived at that time in the eastern Ukrainian oblasts, $22.9 \%$ in western Ukraine, $19.5 \%$ in central Ukraine, $17.4 \%$ in northern Ukraine and $15.1 \%$ in southern Ukraine.

- In 2013 (and thus in the last year for which the DSSU (ДССУ) statistics on the population of the Autonomous Republic of Crimea and Sevastopol are available), the quartile group with the largest population overlapped with the quartile group of the oblasts with the highest population in 2004. This situation was similar at the time to the quartile group of the least populated oblasts.

- This year, $24.5 \%$ of the population of Ukraine (or $25.8 \%$ of the population of the country without the Crimean Peninsula) lived in eastern Ukraine, $23.5 \%$ in western Ukraine (24.7\%), and central Ukraine $19.0 \%$ (20.0\%), northern Ukraine $17.7 \%$ (18.7\%) and southern Ukraine $15.4 \%$. The population of the Autonomous Republic of Crimea and Sevastopol at that time was about 2.4 million people, which constituted $5.2 \%$ of the country's population (Map 4.5).

- In 2017 (i.e., three years after Russia's annexation of the Crimean Peninsula), the group of 6 oblasts with the highest demographic potential included once again the Donetsk Oblast in eastern Ukraine $(9.9 \%$ of the population of Ukraine without the Crimean Peninsula), Dnipropetrovsk in central Ukraine (7.6\%), Kyiv (6.9\%), the Kharkiv Oblast in eastern Ukraine (6.3\%), Lviv in the west of Ukraine $(6.0 \%)$ and Odesa in the south $(5.6 \%)$. The oblasts with the lowest demographic potential were Chernivtsi in western Ukraine $(2.1 \%)$, Kirovohrad in central Ukraine $(2.3 \%)$, Chernihiv in northern Ukraine $(2.4 \%)$, and Volyn in western Ukraine (2.4\%), Kherson in southern Ukraine $(2.5 \%)$ and Ternopil in western Ukraine (2.5\%). 


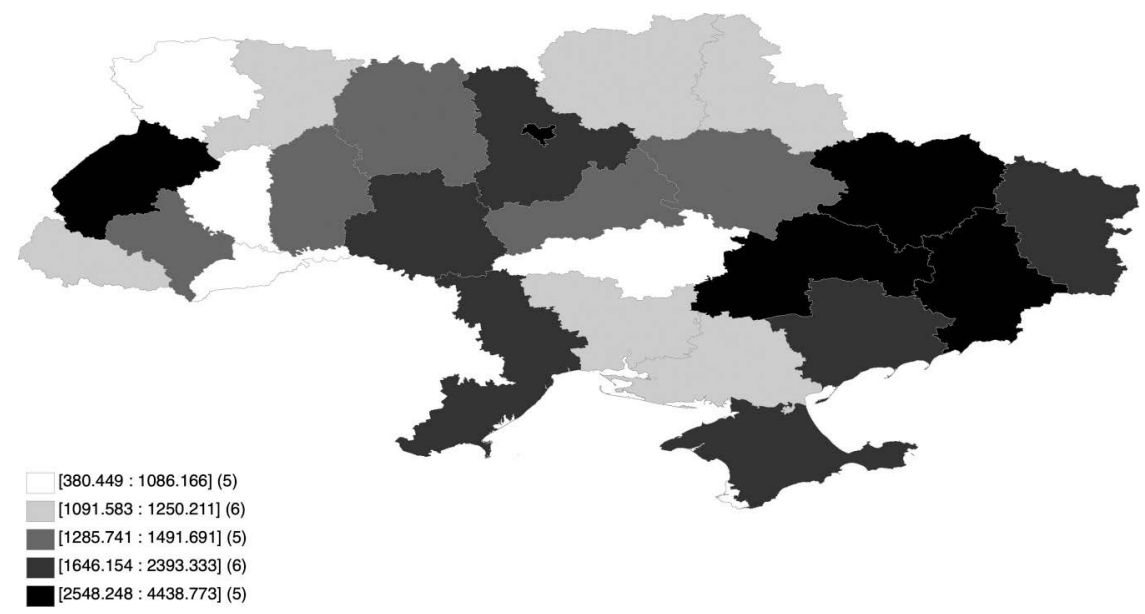

Map 4.5 Population in oblasts between 2004 and 2017 (1,000 people). In the case of the ARC and Sevastopol in 2004-2013.

Source: Our own estimates based on: http://www.ukrstat.gov.ua/ (access: 2019-12-30).

- In $2017,25.5 \%$ of the population of Ukraine lived in eastern Ukraine, $25.0 \%$ in western Ukraine, $19.8 \%$ in central Ukraine, $18.9 \%$ in northern Ukraine and $10.8 \%$ in southern Ukraine. The population of Ukraine between 2004 and 2017 fell from 46.5 million people to 42.5 million people (i.e. a decline of $10.5 \%$ ). If we consider the population of Ukraine without the Crimean Peninsula, then in 2004-2017 it fell from 45.1 million people to 42.5 million people (i.e. by 2.6 million people). Also taking into account the fact that in the years 2004-2017, the population of the capital of Kyiv increased from 2.6 million people to 2.8 million people, it will turn out that the population in the provinces of Ukraine (except for Kyiv and the Crimean Peninsula annexed by Russia) dropped from 42.4 million people to 39.6 million people, that is, by 2.9 million people (roughly the population of Kyiv) or $6.8 \%$ of the population of this part of Ukraine.

- If we compare the population in 2004 and 2017 in the oblasts of Ukraine, it will turn out that only in two oblasts (Kyiv in the north and the Zakarpattia oblasts in the west of Ukraine) the population increased, while in others it decreased. In Kyiv, the population increased by $10.5 \%$, while in the Zakarpattia Oblast by $0.7 \%$ (which in absolute numbers results in only 8.7 thousand people). The largest (exceeding 10\%) relative declines in the population were recorded in the following oblasts: Chernihiv (14.2\%) and Sumy (12.2\%) in northern Ukraine, Kirovohrad (12.0\%) in central Ukraine and Luhansk (11.2\%) in eastern Ukraine, Cherkasy $(10.2 \%)$ and Poltava (10.2\%) in central Ukraine and Donetsk (10.1\%) in eastern Ukraine. 
- In 2017, the capital city Kyiv definitely had the highest population density $\left(3,600\right.$ people $\left./ \mathrm{km}^{2}\right)$. High values of this characteristic were also noted in the following regions: Donetsk (eastern Ukraine, 159.3 persons/ $\mathrm{km}^{2}$ ), Lviv (western Ukraine, 116.1 persons $/ \mathrm{km}^{2}$ ), Chernivtsi (western Ukraine, 112.0 persons $/ \mathrm{km}^{2}$ ) and Dnipropetrovsk (central Ukraine, 101.3 people $/ \mathrm{km}^{2}$ ). The lowest population density (below 45 people $/ \mathrm{km}^{2}$ ) was observed in the following oblasts: Chernihiv $\left(32.2\right.$ people $\left./ \mathrm{km}^{2}\right)$ in the north of Ukraine, Kherson Oblast (36.9 people $/ \mathrm{km}^{2}$ ) in the south, and the Kirovohrad Oblast (39.1 people $/ \mathrm{km}) \mathrm{km}^{2}$ ) and Zhytomyr Oblast (41.5 people $/ \mathrm{km}^{2}$ ) in the north of Ukraine. In the Russianoccupied Crimean Peninsula in 2013, the population density in 2013 was 427.4 persons $/ \mathrm{km}^{2}$ in Sevastopol and 75.3 persons $/ \mathrm{km}^{2}$ in the ARC, respectively.

- The eastern Ukrainian oblasts had the highest population density in 2017 (96.9 people $/ \mathrm{km}^{2}$ ). The next most important were the regions in the west of Ukraine $\left(80.8\right.$ people $\left./ \mathrm{km}^{2}\right)$, the north $\left(70.2\right.$ people $\left./ \mathrm{km}^{2}\right)$ and in the center $\left(63.5\right.$ people $\left./ \mathrm{km}^{2}\right)$, and the lowest population density was in the southern Ukrainian (oblasts: Odesa, Mykolayiv and Kherson, 53.0 people $\left./ \mathrm{km}^{2}\right)^{7}$

Figure 4.3 illustrates the trajectories of the population in groups of Ukrainian oblasts. The following conclusions can be drawn from this chart. First of all, there were declines in population in all the groups of Ukrainian oblasts in the years 2004-2017. Second, the largest losses were recorded in the south of Ukraine (where the population dropped from 7.2 million in 2004 to 4.6 million at the end of the period researched). However, this was mainly due to the annexation of Crimea in 2014. In the remaining oblasts of southern Ukraine

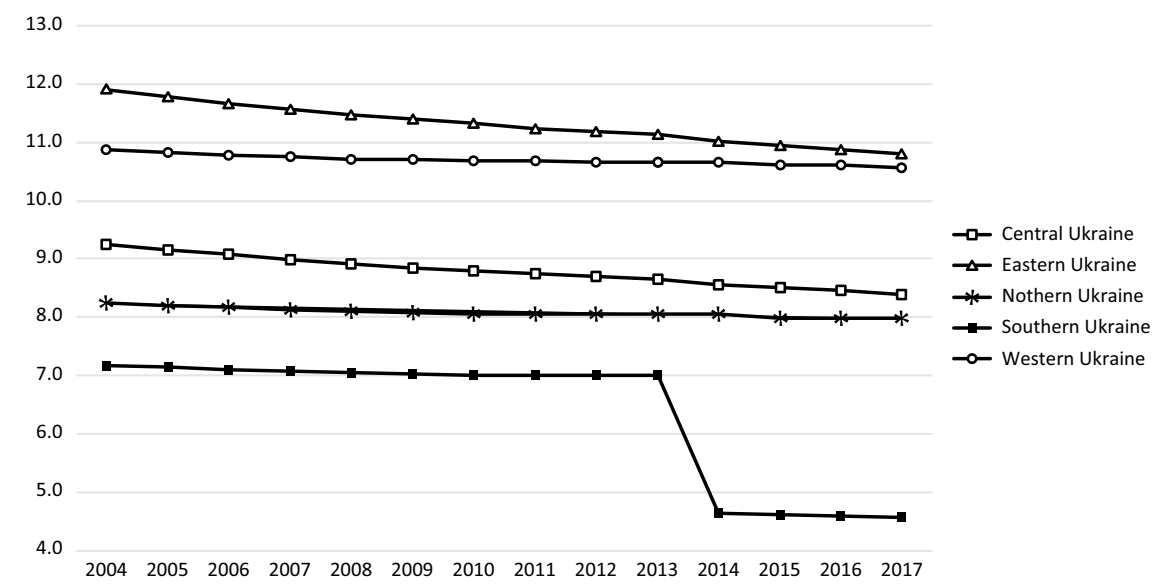

Figure 4.3 Population in groups of oblasts, between 2004 and 2017 (million people). Source: Our own estimates based on: http://www.ukrstat.gov.ua/ (access: 2019-12-30). 
(i.e., Odesa, Mykolayiv and Kherson), the population dropped from 4.8 million people in 2004 to 4.6 million people in 2017 (i.e. by 233,300 people). Third, in eastern Ukraine the number of inhabitants in the given time period decreased by 1.1 million persons, in central Ukraine by 863,300 persons, in the west by 302,400 people and in the north of Ukraine by 262,200 people. Fourth, if you consider the fact that in the years 2004-2017 the population of Kyiv increased by 236,000 people, it turns out that in the oblasts of northern Ukraine with the exception of Kyiv (i.e., Chernihiv, Kyiv, Sumy and Zhytomyr) the population dropped by almost 500,000 people.

Table 4.5 summarizes statistical data on the population of Ukrainian cities with a population exceeding 200,000 residents in 2001 and 2017. From statistical data it can be concluded that:

- In 2001, 32 Ukrainian cities had a population of over 200,000. In 2017 (after the annexation of the Crimean Peninsula by Russia) there were 30 such cities, as Simferopol and Sevastopol have been de facto, outside of Ukraine's jurisdiction since 2014.

- In both 2001 and 2017, the capital City of Kyiv was by far the largest Ukrainian city. Over the 16 years considered, the population of Kyiv increased by $12.0 \%$.

- In 2001, the population of 4 cities in Ukraine (except Kyiv) exceeded one million people. They were Kharkiv (1.5 million people) and Donetsk (1.0 million people) in eastern Ukraine, Dnipro (1.1 million people) in central Ukraine and Odesa (1.0 million people) in southern Ukraine.

- The largest city with a population of between 500,000 and one million inhabitants is Zaporizhzhya in the east, followed by Lviv in the west, Kryvyi Rih in the center and Mykolayiv in the south of Ukraine.

- Out of the remaining cities with over 200,000 inhabitants, six were located in central Ukraine (Vinnytsya, Poltava, Cherkasy, Kamianske, Kropyvnytskyi and Kremenchuk), four in eastern Ukraine (Mariupol, Luhansk, Makiyivka and Horlivka), four in northern Ukraine (Chernihiv, Sumy, Zhytomyr and Bila Tserkva), three in southern Ukraine (Simferopol, Sevastopol and Kherson) and six cities in western Ukraine (Khmelnytskiy, Rivne, Chernivtsi, Ternopil, Ivano-Frankivsk and Lutsk).

- $29.5 \%$ of those living in cities of more than 200,000 lived in eastern Ukraine, $22.0 \%$ in northern Ukraine (of which $70.7 \%$ in Kyiv), $20.6 \%$ in central Ukraine, $15.3 \%$ in southern Ukraine and $12.7 \%$ in western Ukraine.

- In 2017, the situation changed (compared to 2001) to the extent that the cities of Dnipro and Donetsk ceased to maintain a population of over one million (the population of the Dnipro fell by $8.3 \%$ to 976,500 people, and Donetsk by $8.8 \%$ to 927,200 people), while Mykolayiv ceased to be a city of over half a million (the population of this city dropped by $4.5 \%$ to 490,800 people). 
- In the last period surveyed, $29.0 \%$ of people living in cities of over 200,000 lived in eastern Ukraine, 25.1\% in northern Ukraine (of which $73.9 \%$ in Kyiv), $20.6 \%$ in central Ukraine, $13,8 \%$ in western Ukraine and $11.4 \%$ in southern Ukraine (not counting around 650,000 - the populations of Simferopol and Sevastopol).

- Comparing the population of the cities analyzed here, it turns out that the population of seven of these cities increased, while the remaining decreased. Growing populations were noted in (as was already mentioned) Kyiv (an increase of $12.0 \%$ ) in northern Ukraine; Chernivtsi (10.6\%), Ivano-Frankivsk (6.9\%) and Khmelnytskiy (5.7\%) in western Ukraine; Vinnytsya (4.5\%), in central Ukraine; Lutsk (3.9\%) in western Ukraine; and Bila Tserkva (3.8\%) in northern Ukraine. The largest (exceeding $10 \%$ ) population decreases were recorded in Horlivka $(15.2 \%)$, Makiyivka (10.8\%) and Luhansk (10.7\%) in the Donbass and Kherson $(10.7 \%)$ in the south of Ukraine.

- In 2017, the number of people living in cities of more than 200,000 fell by $6.1 \%$, (excluding the number of inhabitants of Simferopol and Sevastopol) where this chart dropped by $2.1 \%$. In northern Ukraine, the value of this statistic increased by $7.2 \%$, and in western Ukraine by $2.2 \%$. In the remaining groups of oblasts, the population living in cities of more than 200,000 fell by $5.8 \%$ in central Ukraine, $7.4 \%$ in the east of Ukraine and $29.8 \%$ in the south, respectively (excluding Simferopol and Sevastopol, where a drop of $4 \%$ was recorded).

Figure 4.4 illustrates the trajectories of the urban population in groups of oblasts in 2004-2017. The following conclusions can be drawn from this figure:

- The largest percentage of the urban population in Ukraine was in eastern Ukraine (nine to ten million people). Next came the oblasts of northern and central Ukraine (5.7-6.2 million people, respectively), and western Ukraine (approx. 5.3 million people). The least numerous were the cities of the southern Ukrainian oblast (3.0-4.7 million people).

- In the north of Ukraine, the population living in cities increased by 165,000 people. However, this was mainly due to the growing number of residents of the capital, Kyiv. In other cities of northern Ukraine, this chart fell by 107,400 people.

- Also, in western Ukraine, the number of urban residents increased (by 50,000 people).

- In the remaining groups of Ukrainian oblasts, the number of city dwellers was falling. In central Ukraine, this chart fell by 354,300 people, and in eastern Ukraine by 759,000 people.

- The largest decreases in the population in cities in 2004-2017 were recorded in southern Ukraine. There was a decrease in this volume, of approximately 1.7 million people. However, this decline was mainly due to the annexation of the Crimean Peninsula. In the Odesa, Mykolayiv and Kherson oblasts, the population living in cities fell (between 2004 and 2017) from 3.1 million people to 3.0 million people. 


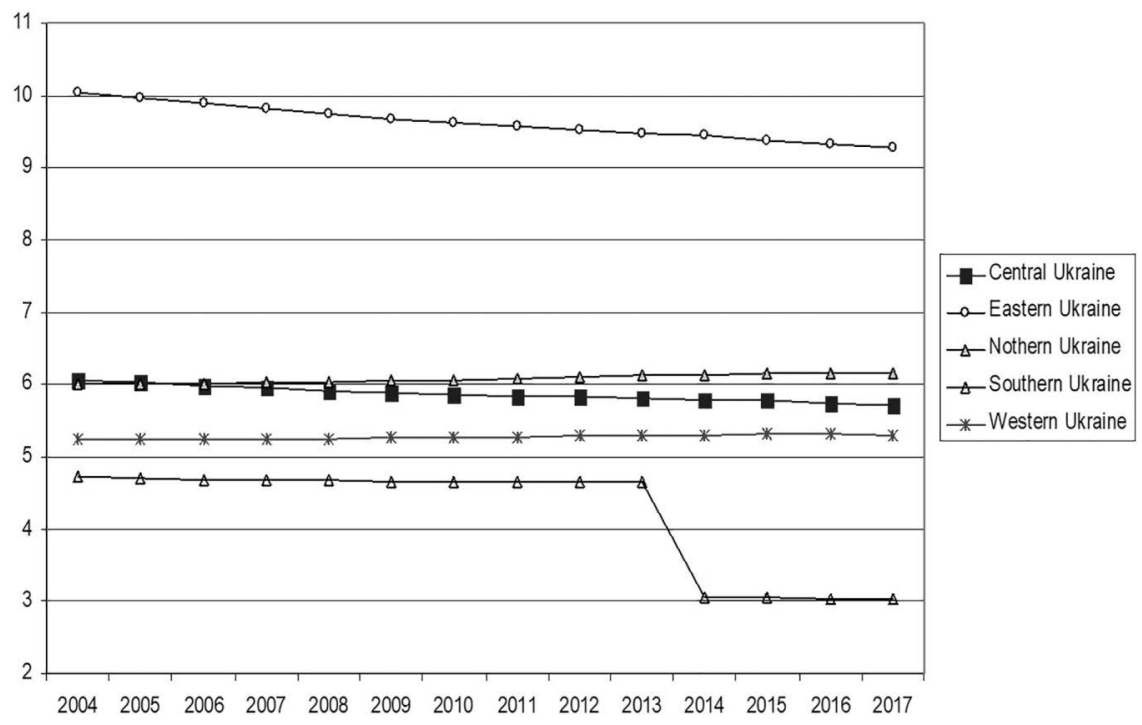

Figure 4.4 Population in groups of oblasts, between 2004 and 2017 (million people). Source: Our own estimates based on: http://www.ukrstat.gov.ua/ (access: 2019-12-30).

Figure 4.5 illustrates the trajectories of the population living in the countryside in groups of Ukrainian oblasts in 2004-2017. The following conclusions can be drawn from the data illustrated in this figure:

- In contrast to the population living in cities, the highest part of the rural population in Ukraine was located in western Ukraine. In the years 2004-2017 about 5.3-5.6 million people lived in the countryside. In central Ukraine, around 2.7-3.2 million people lived in the countryside, in northern Ukraine about 1.8-2.2 million people and in the east only $1.5-1.9$ million people. In southern Ukraine, on the other hand, mainly as a result of the Russian armed intervention of 2014 and the annexation of the Crimean Peninsula, the number of people living in villages fell from 2.5 million people, in 2014, to 1.5 million people in 2017 (in 2013, i.e., directly before the annexation of Crimea, the number of the rural population in the Crimean Peninsula was 756,700 people).

- The rural population is steadily decreasing in all groups of Ukrainian oblasts. The largest absolute decreases in the population living in the countryside were recorded in the south of Ukraine (914,400 people between 2004 and 2017), then in central Ukraine (509,000), northern Ukraine (427,900 persons), western Ukraine (352,400 persons), while the smallest was in eastern Ukraine (337,400 persons). 


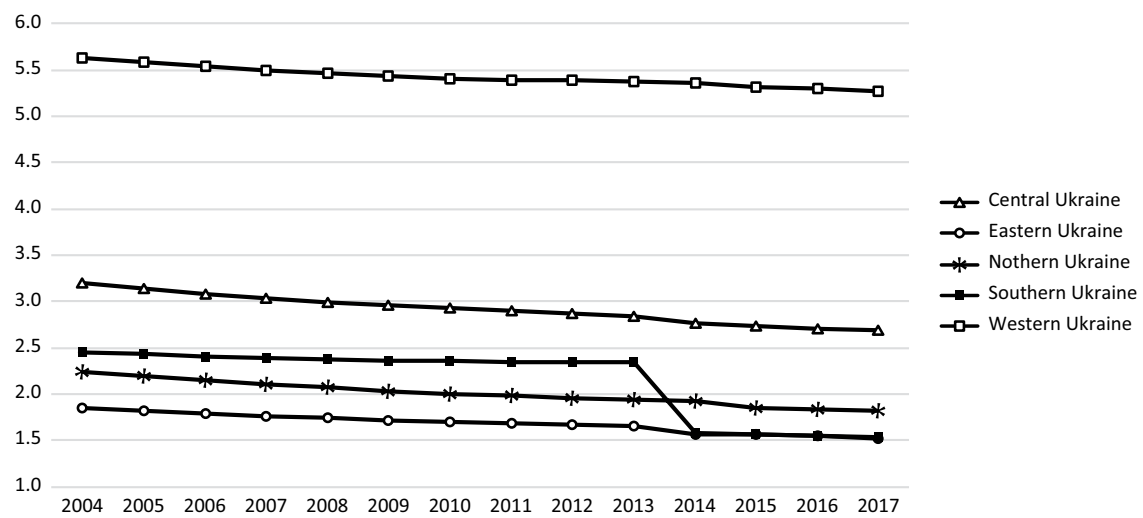

Figure 4.5 Village population in oblast groups in 2004-2017 (million people). Source: Our own estimates based on: http://www.ukrstat.gov.ua/ (access: 2019-12-30).

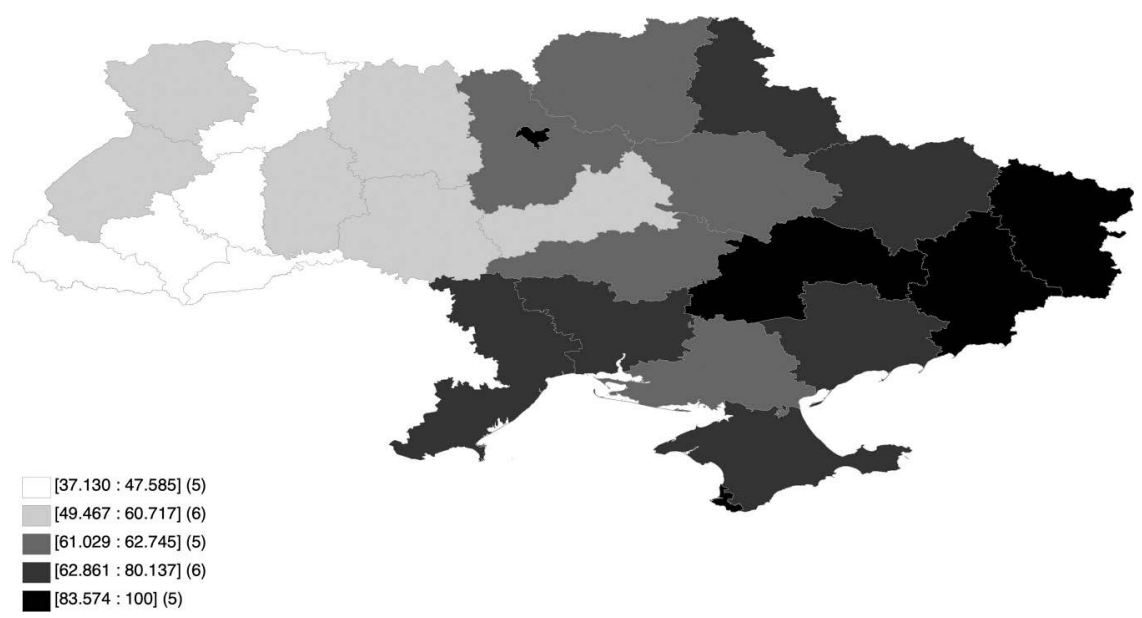

Map 4.6 Urbanization rates in oblasts in 2004-2017 (\%) In the case of the ARC and Sevastopol in 2004-2013.

Source: Our own estimates based on: http://www.ukrstat.gov.ua/ (access: 2019-12-30).

Map 4.6 illustrates the spatial differentiation of urbanization rates in Ukrainian oblasts (on average in 2004-2017), while Figure 4.6 shows the trajectories of these rates in groups of oblasts in the researched timeframe. The following map and the chart show as follows:

- What is natural, by far the highest urbanization rates were recorded in those cities with a special status (i.e. Kyiv and Sevastopol). In Kyiv, this rate was 100\%, while in Sevastopol (on average in 2004-2013) 93.9\%.

- Very high urbanization rates were also recorded in the Donbass (Donetsk 90.7\% and Luhansk 86.8\%) in eastern Ukraine, the Dnipropetrovsk 
Oblast $(83.6 \%)$ in central Ukraine and the Kharkiv $(80.1 \%)$ and Zaporizhzhya $(76.9 \%)$ oblasts in eastern Ukraine.

- In six oblasts, urbanization rates were lower than $50 \%$. These were the following oblasts: Zakarpattia (37.1\%), Chernivtsi (42.1\%), IvanoFrankivsk (43.2\%), Ternopil (43.8\%) and Rivne $(47.6 \%)$ in western Ukraine and the Vinnytsya Oblast $(49.5 \%)$ in central Ukraine, bordering on both western Ukraine ${ }^{8}$ and Moldova.

- A more general conclusion can be drawn from this, that is, that the oblasts of the left-bank and southern Ukraine, more strongly integrated in the past with Russia or the Soviet Union, are still characterized by a much higher level of urbanization than the right-bank part of this country (see also data in Table 4.5 and Figure 4.6).

Figure 4.6 shows the trajectories of urbanization rates in groups of Ukrainian oblasts in 2004-2017. From statistical data it can be concluded that:

- Eastern Ukrainian oblasts had by far the highest rates of urbanization (around 85\%). Lower urbanization rates were around 10 percentage points in the north of Ukraine, which was mainly due to the demographic potential of the capital City of Kyiv.

- In the oblasts of central Ukraine, the average urbanization rates in 2004-2017 were about $66.8 \%$, while in central Ukraine $66.2 \%$. The lowest urbanization rates were recorded in the peripheral western Ukraine (49.3\%), where (as has already been mentioned) there is only one large city.

- Urbanization rates were increasing in all oblasts groups. These rates increased the fastest in northern Ukraine (by 4.5 percentage points), then in central Ukraine (2.5 percentage points), western (1.9 percentage points), eastern (1.5 percentage points) and southern Ukraine ( 0.5 percentage points).

- The increase in urbanization rates in northern Ukraine is mainly due to the very dynamic increase in the population of Kyiv, combined with the gradual depopulation of the rest of this part of Ukraine. In the remaining groups of oblasts, the increasing rates of urbanization are mainly due to the fact that Ukrainian villages are depopulating faster than Ukrainian cities.

- In all 25 Ukrainian regions (except the Autonomous Republic of Crimea and Sevastopol), urbanization rates were higher in 2017 than in 2004. These rates increased the fastest (by over 3 percentage points) in the Chernihiv region (by 6.3 percentage points) in northern Ukraine, Khmelnytskiy (5.0 percentage points) in western Ukraine, Vinnytsya (4.3 percentage points) in central Ukraine, Sumy (3.8 percentage points) in northern Ukraine, Poltava (3.4 percentage points) in central Ukraine, Kyiv (3.2) in northern Ukraine and Cherkasy (3.0 percentage points) in central Ukraine. In the whole of Ukraine, the urbanization rate increased by 2.1 percentage points. 
82 Nataliia Chugaievska et al.

Table 4.5 The population in Ukrainian cities with more than 200,000 inhabitants in 2001 and 2017 (1,000 people)

\begin{tabular}{|c|c|c|c|c|}
\hline \multirow[t]{2}{*}{ City } & \multirow[t]{2}{*}{ Oblast } & \multicolumn{2}{|c|}{ Population in a year } & \multirow{2}{*}{$\begin{array}{l}\text { Population } \\
\text { in } 2017 \text { (year } \\
2001=100)\end{array}$} \\
\hline & & 2001 & 2017 & \\
\hline Kyiv (Kü̈в) & City of Kyiv & $2,611.3$ & $2,925.8$ & 112.0 \\
\hline Kharkiv (Харків) & Kharkiv Oblast & $1,470.9$ & $1,439.0$ & 97.8 \\
\hline Odesa $(O \partial e c a)$ & Odesa Oblast & $1,029.0$ & $1,010.8$ & 98.2 \\
\hline Dnipro (Дніпро) & Dnipropetrovsk Oblast & $1,065.0$ & 976.5 & 91.7 \\
\hline Donetsk (Донецьк) & Donetsk Oblast & $1,016.2$ & 927.2 & 91.2 \\
\hline $\begin{array}{l}\text { Zaporizhzhya } \\
\text { (Запоріжжя) }\end{array}$ & Zaporizhzhya Oblast & 815.3 & 750.7 & 92.1 \\
\hline Lviv (Львiв) & Lviv Oblast & 732.8 & 728.0 & 99.3 \\
\hline Kryvyi Rih (Кривий Ріг) & Dnipropetrovsk Oblast & 669.0 & 636.3 & 95.1 \\
\hline Mykolayiv (Миколаїв) & Mykolayiv Oblast & 514.1 & 490.8 & 95.5 \\
\hline Mariupol (Маріуполь) & Donetsk Oblast & 492.2 & 449.5 & 91.3 \\
\hline Luhansk (Луганськ) & Luhansk Oblast & 463.1 & 413.4 & 89.3 \\
\hline Vinnytsya (Вінницяя) & Vinnytsya Oblast & 356.7 & 372.7 & 104.5 \\
\hline Makiyivka (Макіївка) & Donetsk Oblast & 389.6 & 347.4 & 89.2 \\
\hline Kherson (Херсон) & Kherson Oblast & 328.4 & 293.3 & 89.3 \\
\hline Poltava (Полтава) & Poltava Oblast & 318.0 & 292.0 & 91.8 \\
\hline Chernihiv (Чернігів) & Chernihiv Oblast & 305.0 & 291.6 & 95.6 \\
\hline Cherkasy (Черкаси) & Cherkasy Oblast & 295.4 & 281.5 & 95.3 \\
\hline $\begin{array}{l}\text { Khmelnytskiy } \\
\text { (Хмельницьький) }\end{array}$ & Khmelnytskiy Oblast & 254.0 & 268.5 & 105.7 \\
\hline Zhytomyr (Житомир) & Zhytomyr Oblast & 284.2 & 267.4 & 94.1 \\
\hline Chernivtsi (Чернівиі) & Chernivtsi Oblast & 240.6 & 266.0 & 110.6 \\
\hline Sumy $(С у м и)$ & Sumy Oblast & 293.1 & 265.6 & 90.6 \\
\hline Horlivka (Горлівка) & Donetsk Oblast & 292.3 & 247.9 & 84.8 \\
\hline Rivne (Рівне) & Rivne Oblast & 248.8 & 247.4 & 99.4 \\
\hline Kamianske (Кам'янське) & Dnipropetrovsk Oblast & 255.8 & 237.2 & 92.7 \\
\hline $\begin{array}{l}\text { Ivano-Frankivsk } \\
\quad(\text { Івано-Франківськ) }\end{array}$ & $\begin{array}{l}\text { Ivano-Frankivsk } \\
\text { Oblast }\end{array}$ & 218.4 & 233.4 & 106.9 \\
\hline $\begin{array}{l}\text { Kropyvnytskyi } \\
\text { (Кропивницький) }\end{array}$ & Kirovohrad Oblast & 254.1 & 229.6 & 90.4 \\
\hline $\begin{array}{l}\text { Kremenchuk } \\
\text { (Кременчук) }\end{array}$ & Poltava Oblast & 234.1 & 222.3 & 95.0 \\
\hline Ternopil (Тернопіль) & Ternopil Oblast & 227.8 & 217.9 & 95.7 \\
\hline Lutsk (Луцькк) & Volyn Oblast & 208.8 & 217.0 & 103.9 \\
\hline $\begin{array}{l}\text { Bila Tserkva } \\
\text { (Біла Церква) }\end{array}$ & Kyiv Oblast & 200.1 & 207.7 & 103.8 \\
\hline $\begin{array}{l}\text { Simferopol } \\
\text { (Сімферополь) }\end{array}$ & $\mathrm{ARC}$ & 343.6 & - & - \\
\hline $\begin{array}{l}\text { Sevastopol } \\
\quad \text { (Севастополь) }\end{array}$ & City of Sevastopol & 342.5 & - & - \\
\hline Central Ukraine & & $3,448.1$ & $3,248.2$ & 94.2 \\
\hline Eastern Ukraine & & $4,939.5$ & $4,575.1$ & 92.6 \\
\hline North Ukraine & & $3,693.8$ & $3,958.1$ & 107.2 \\
\hline South Ukraine & & $2,557.6$ & $1,794.8$ & 70.2 \\
\hline Western Ukraine & & $2,131.2$ & $2,178.1$ & 102.2 \\
\hline Ukraine & & $16,770.1$ & $15,754.4$ & 93.9 \\
\hline & & $16,084.1^{\mathrm{a}}$ & & $97.9^{\mathrm{a}}$ \\
\hline
\end{tabular}

Source: Our own estimates based on: http://www.ukrstat.gov.ua/ (access: 2019-12-30).

a Ukraine without the ARC and Sevastopol. 


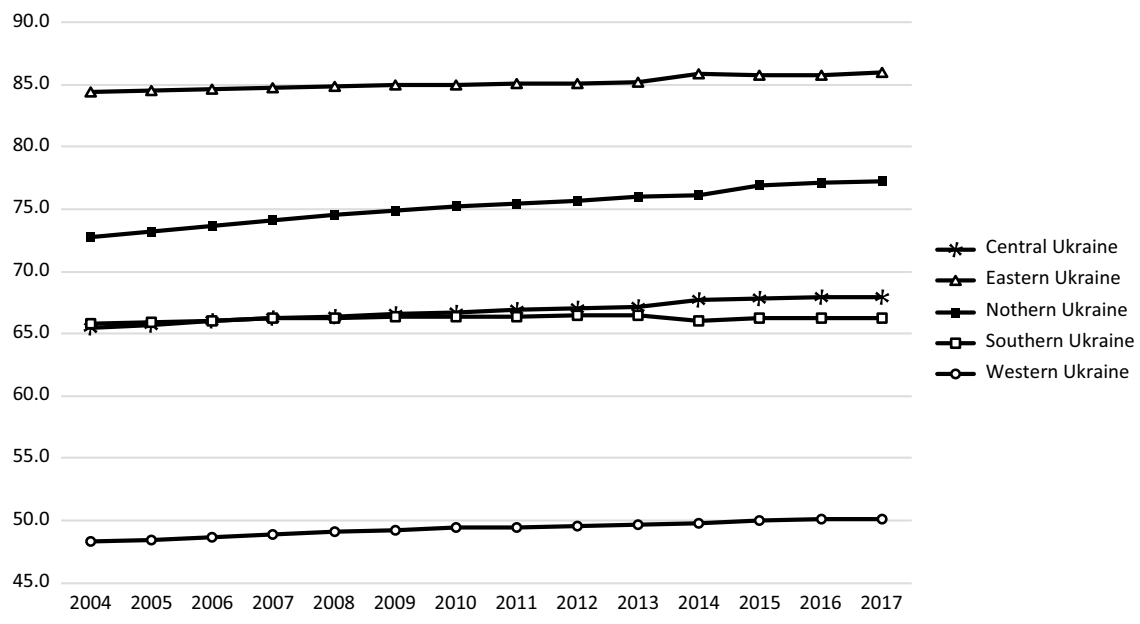

Figure 4.6 Urbanization rates in oblast groups in 2004-2017 (\%).

Source: Our own estimates based on: http://www.ukrstat.gov.ua/ (access: 2019-12-30).

\subsection{Summary}

The considerations can be summarized as follows:

i The Mazowieckie, Śląskie and Wielkopolskie voivodeships were characterized by the largest demographic potential. The lowest potential was found in the Opolskie, Lubuskie, Świętokrzyskie and Podlaskie voivodeships.

ii The group of oblasts with the highest demographic potential was composed of the Donetsk region in the east of Ukraine, Dnipropetrovsk in central Ukraine and the Kharkiv oblasts in the east of that country. Sevastopol in the Crimea and the Chernivtsi and Volyn oblasts in western Ukraine were characterized by having the lowest population.

iii In the voivodeship groups, the largest population was recorded in the voivodeships of central Poland (about 15 million people), followed by Western Poland (about ten million people) and eastern Poland (about eight million people). In the voivodeships of western and central Poland, the population had a slight upward trend, while in eastern Poland it was decreasing.

iv In 2017, about a quarter of the population of Ukraine lived in the east of this country, $1 / 4$ in the west, almost $20 \%$ in central and northern Ukraine and just over $10 \%$ in southern Ukraine.

v All oblast groups in the years 2004-2017 suffered a decrease in population. The population declined by far the fastest in southern Ukraine (due to the Russian annexation of the Crimean Peninsula), and then 
in the oblasts of the pro-Russian separatists in the regions of eastern Ukraine (Donbas). The lowest drops in population were recorded in the west and north of Ukraine.

vi The voivodeships of central Poland had the highest population density, followed by Mazowieckie Voivodeship, the western Poland voivodeships, and the smallest value of this variable (over two times lower than in Central Poland) was in the voivodeships of eastern Poland.

vii In 2017, the industrial oblasts of eastern Ukraine were by far the highest in population density. Next in line (due to the value of this variable) were the oblasts of western, northern, central and southern Ukraine.

viii In 2004, there were 18 cities in Poland with a population exceeding 200,000 persons, and in 2017 there were 16 (the population of Gliwice and Kielce fell below 200,000). Among the largest Polish cities, the population of Warsaw is growing the fastest, while Łódź and the cities of the Górny Śląsk-Zagłębie agglomeration are depopulating the fastest. What's more, the total population of all cities of over 200,000 inhabitants in eastern Poland was lower than the population of Warsaw. The situation was similar with the total population of cities of over 200,000 in western Poland.

ix In 2001, there were 32 cities in Ukraine over 200,000; since 2014 (after the Russian annexation of the Crimean Peninsula, in which Sevastopol and Simferopol are located), the number of these cities has dropped to 30. By far, the fastest growth in population in the years 2001-2017 was noted in the capital of Kyiv and in the city of Chernivtsi, located near the borders with Romania and Moldova, in the province of Bukovina. The population of Ivano-Frankivsk and Khmelnytskiy in western Ukraine, Vinnytsya in central Ukraine, Lutsk in western Ukraine and Bila Tserkva in northern Ukraine also increased. The population of Horlivka, Makiyivka and Luhansk in Donbas and Kherson in the south of Ukraine fell the fastest. In 2017, the total population of cities of more than 200,000 in western or southern Ukraine was smaller than the population of Kyiv.

$\mathrm{x}$ The highest rates of urbanization were found in central Poland (mainly due to the Górny Śląsk-Zagłębie agglomeration) and the Mazowieckie Voivodeship (due to the Warsaw agglomeration), followed by western Poland, and the lowest (in the case of population density) was in the agricultural voivodeships of eastern Poland (where these rates were more than 15 percentage points lower than in the Mazowieckie Voivodeship).

xi In the most industrialized regions of eastern Ukraine, urbanization rates were around $85 \%$. Next in terms of urbanization rates were the oblasts located in the north of Ukraine (about $75 \%$ ), in central and southern Ukraine (over 65\%) and the lowest (below 50\%) in the oblasts of western Ukraine.

xii In all groups of voivodeships (except for the voivodeships of eastern Poland) urbanization rates fell in 2004-2017. This resulted mainly from 
the fact that a part of the population of the urban districts moved to neighboring villages. On the other hand, the growing urbanization rates in eastern Poland were the result of the fact that the number of the rural population in this part of Poland fell slightly faster than the number of the urban population.

xiii In contrast, in Ukraine, urbanization rates were rising in all oblasts groups. This resulted from the fact that Ukrainian villages depopulated in the analyzed period of time, much faster than Ukrainian cities.

\section{Notes}

1 At that time, the Volhynian Voivodeship also included the city of Rivne, which is now the capital of the Rivne Oblast.

2 For a more extensive description of the general characteristics and division of Ukrainian provinces into group of oblasts see, e.g. Tokarski, Chugaievska, Chugaievska (2019).

3 Left-bank Ukraine (Right Bank Ukraine) is the part of Ukraine that lies on the left (right) of the largest Ukrainian river - the Dnieper. In left-bank Ukraine there are therefore the following oblasts: Sumy, Chernihiv, Kharkiv, Luhansk, Donetsk, most of the Zaporizhia oblasts, the eastern parts of the Kyiv, Cherkasy and Dnipropetrovsk regions, the south-eastern part of the Cherkasy oblast and the Autonomous Republic of Crimea.

4 The population of Gliwice fell below 200,000 persons in 2005, and Kielce in 2013.

5 The first (second, third, fourth) quartile group will be understood hereinafter as a set of provinces or oblasts characterized by the value of the analyzed statistical feature higher than the third quartile (between the third and fourth quartiles, between the second and third quartiles, lower than the third quartile).

6 It seems that the low level of urbanization in the Małopolskie voivodeship results from the mountainous terrain found in the southern part of this voivodeship.

7 In 2013, the population density of the southern Ukraine oblasts together with the ARC and Sevastopol was 61.7 people $/ \mathrm{km}^{2}$.

8 Urbanization rates were also low in other western Ukrainian oblasts. In the Volyn oblast, the average urbanization rates in 2004-2017 were $51.6 \%$, in the Khmelnytskyi oblast $54.6 \%$, and only in the Lviv oblast (mainly due to the urban potential of Lviv) did these rates exceed $60 \%$ (on average in the period considered here they were $60.7 \%$ ). 